研究論文

\title{
回転平膜を用いた膜分離高濃度活性污泥法における嚗気制御 による有機物およひ空素の同時除去に関する研究
}

今井 剛* ·呂 樹光* 浮田正夫* ·関根雅彦 $*$. 樋口隆哉* ·深川勝之 $* *$

\begin{tabular}{|c|}
\hline 要 \\
\hline 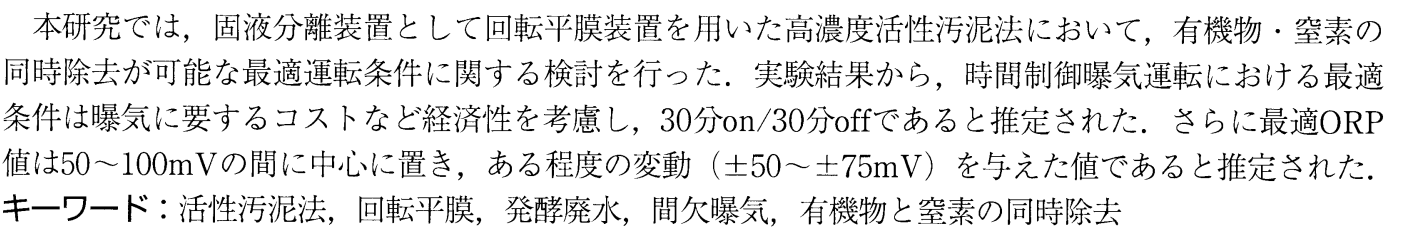 \\
\hline
\end{tabular}

\section{1. 緒 言}

世界的に水環境の保全が重要課題として取り上げ られている中で，わが国の水環境保全については閉 鎖性水域（あるいは海域）の富栄養化防止が急務で あり，したがって廃水中の有機物のみならず窒素, リンについても十分な除去が不可欠となっている. 産業廃水の処理においては，一般にその濃度が高い こと, 場合によっては生物難分解性成分を多く含む こと等から，それぞれの廃水に適した処理システム の構築が必要である. 高濃度活性污泥法は, 固液分 離装置に膜分離装置を組み込むことにより，污泥の 高濃度化が容易となり, 難分解性物質を含有する廃 水の処理や高負荷処理が可能なプロセスとして注目 されている. 高濃度活性污泥法は通常単槽式プロセ スとして運転されているが，単槽式プロセスにおい て有機物の除去だけでなく窒素の除去をも考えた場 合, 有機物除去, 硝化, 脱窒反応が同時に行われる ように反応槽内の曝気量を適正に制御しなければな らない. 曝気量の制御方法として, 時間制御による 方法 ${ }^{1,2)}$ や, 酸化還元電位 (ORP) による方法 ${ }^{34)}$ 等 に関する研究がなされている。しかしながら，

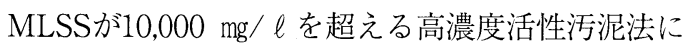
おける曝気制御による有機物および空素の同時除去
に関する研究は少なく, 生物難分解性物質を含む産 業廃水等の処理に対する適用例も少ない.

そこで，本研究では，固液分離装置として回転平 膜装置5 8) を用いた高濃度活性污泥法9,10)において 有機物・窒素の同時除去が可能な最適運転条件に関 する検討を行う，硫酸塩およびアンモニアを高濃度 に含有するアミノ酸系発酵工場からの有機性高濃度 廃水を対象に，曝気の制御を時間的に行うことによ る有機物除去, 硝化, 脱窒が同時進行する最適曝気 運転条件について実験的に検討する. 次に，微生物 の状態を的確に把握しながら曝気の制御が可能な ORP制御運転を同様の装置, 廃水に対して行い, 最 適ORP值を推定する。ささらにそのORP值付近にお いてORP值を変動させる制御運転を行い，有機物お よび窒素の除去率, 運転コス卜等から最適運転条件 を推定する。

\section{2．実験装置および方法}

\section{1 実験装置}

本研究で用いた実験装置の概略図を図ー 1 に示 す. 反応槽は, アクリル製の円筒形で総容積約 $45 \ell$, 有効反応容積約 $30 \ell$ である. 回転平膜装置（容積約

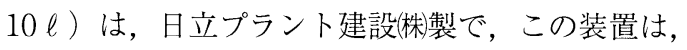
膜槽, 膜駆動部, 処理ポンプ, 制御盤からなり, 装

*山口大学工学部社会建設工学科

$* *$ 宇部工業高等専門学校物質工学科
1999年 9 月 17 日受付 2000年 1 月 29 日受理 


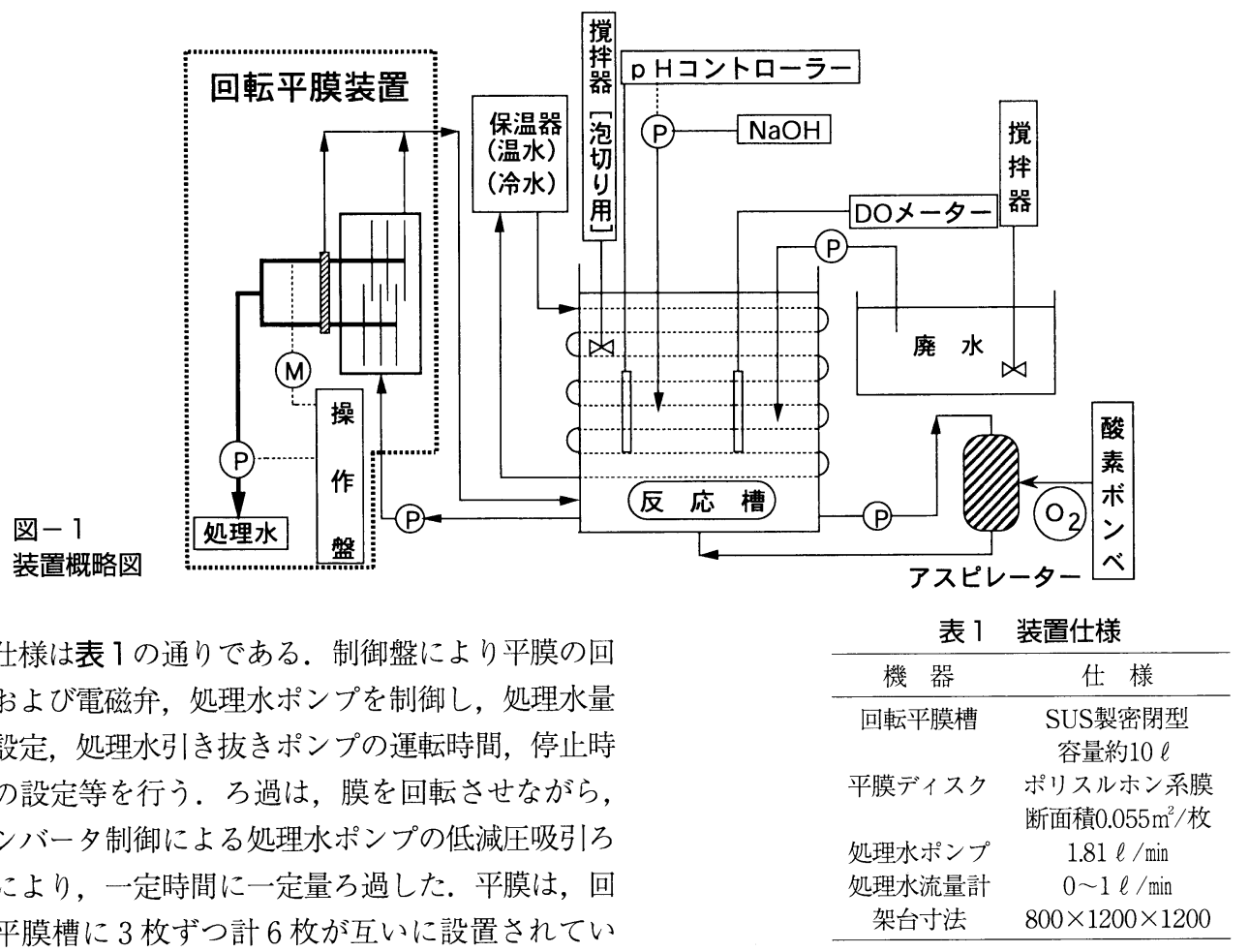

る. 膜を互いに逆方向に回転させ，そのせん断力に より付着した污泥を取り除くことが可能である。さ らに，膜を回転させながら時間設定によりろ過のみ を停止させ，膜面の污れを洗浄できる．本実験装置 の膜の分画分子量 (ポアサイズ) は約 750,000（0.03 $\mu \mathrm{m}$ 程度）であるが，污泥が高濃度に集積されるに したがい，膜の目詰まり，すなわちファウリングが 生じた。そのため設定負荷を上昇させる毎に，ある いは膜の目詰まりが顕著になる毎に膜を約 $500 \mathrm{mg} / \ell$ の次亜塩素酸ナトリウムにより洗浄した.

\section{2 実験方法}

図ー1に示すように曝気装置には酸素供給効率の 高いアスピレーターを採用した。さらにDOが不足 する場合には純酸素曝気を併用して，設定した条件 で曝気を行った，時間制御運転時は，曝気の制御を タイマーにより時間的なエアポンプの on-off 制御で 行った。また，ORP制御は複合電極（銀／塩化銀） をORP制御装置に接続し，それぞれの設定值でエア

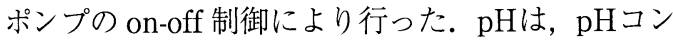
トローラーの on-off 制御により1N-NaOHをマイクロ チューブポンプで反応槽内に送液し，pHを7.0付近 に保った，槽内の温度は，反応槽の外側全体にビ二 ールホースを巻き付け，その中に恒温槽から温水

(夏は冷水) を循環させることによって約 $30^{\circ} \mathrm{C}$ 保 持した。対象とした廃水は硫酸塩およびアンモニア を高濃度に含有する有機性高濃度廃水（アミノ酸系 発酵工場から排出される廃水：以下発酵廃水と略 す）を適宜希釈して，チューブポンプで 1 日に約 15 $\ell$ を反応槽に送入した，発酵廃水の組成を表 2 に示 す.この廃水は $\mathrm{NH}_{4}{ }^{+}-\mathrm{N}, \mathrm{SO}_{4}{ }^{2}-\mathrm{S}$ 濃度が一般の廃水 に比べて非常に高いことが特徵である。 $\mathrm{NH}_{4}{ }^{+}-\mathrm{N} は$ 微生物に対する毒性が高く, また $\mathrm{SO}_{4}{ }^{2}-\mathrm{S} は$ 嫌気的䨌 囲気下で硫酸還元菌により硫化水素を発生して廃水 
処理を担う微生物に阻害をするため，本 研究で対象とする発酵廃水は一般に難分 解性の廃水といえる。滞留時間は, 反応 槽および膜分離槽の合計の容積 $40 \ell$ を考 慮して水理学的滞留時間 (HRT) で約 2.7日である。.また，廃水は固形物を含 むため, 沈殿しないように, 廃水貯留槽 で擋找を行った，膜分離装置からの処理 水引抜き量は $0.1 \ell / \mathrm{min}$, 時間設定を運 転時間 1 分，停止時間 9 分とした。供試 污泥は，山口県宇部市東部下水処理場の返送污泥を 濃縮したものを使用した。なお，余㮃污泥の引抜き は分析のためのサンプリングを除いて全実験期間を 通して行わなかった。

\subsection{1 時間制御運転}

時間制御運転では，曝気の制御を時間的に行うこ とによって有機物除去，硝化，脱窒が同時進行する 最適曝気運転条件を検討した，用いた実験装置は 1 基のみで，表 3 の運転条件にしたがって実験を実施 した．各runは連続的に実施し，実験開始後140日， 180日，および実験終了後に膜洗浄を行った。サン プルは各曝気条件下で処理水質が定常状態に達して から採取し，处理水質に関して，TOC， $\mathrm{NH}_{4}-\mathrm{N}$, T-Nの除去率，NOx-Nの濃度から時間制御運転に関 する最適運転条件を検討した。また，反応槽内の状 態を調べるために, 細胞外ポリマー量, 溶解性物質 としての糖，タンパク量の分析も行った。

\subsubsection{ORP制御運転}

一般に，酸化還元電位 (Oxidation Reduction Potential : ORP) によるモニタリングはDO（溶存 酸素量）によるものに比べて，反応槽内の嫌気，無 酸素，好気状態がよく把握できる。このため，時間 制御運転と比べて，処理効率の向上が期待できる. 図ー2 はORPを $100 \pm 75 \mathrm{mV}$ に設定した場合のORP 時間変化の一例であり，他の設定ORP值においても この図に類似した変化を示した。この図において, ORP值か $25 \mathrm{mV}$ まで下がると曝気を開始し， $175 \mathrm{mV}$ に達すると停止した，実験では，まずORP值を一 $50 \pm 10,0 \pm 10,50 \pm 10,100 \pm 10,150 \pm 10 \mathrm{mVK}$ 設定し，一定の馴致期間の後に反応槽内が定常状態 に達してから, 基質, 槽内液, 処理水のサンプリン グを行い，水質分析（TOC， NH4-N, T-N, NOxN）を行った。これらの実験結果から最適なORP値 の推定を行った. 次に, 推定されたORP值において,
表 3 時間制御曝気運転条件

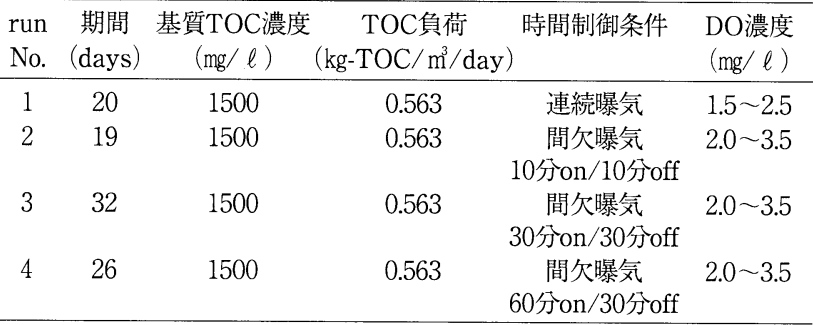

$\mathrm{pH}=7.0$ 処理水流量 $=15 \ell /$ day（on: 純酸素供給） 温度 $=28 \sim 33^{\circ} \mathrm{C} \quad$ 滞留時間 $=2.67$ day (off : 純酸素供給停止)

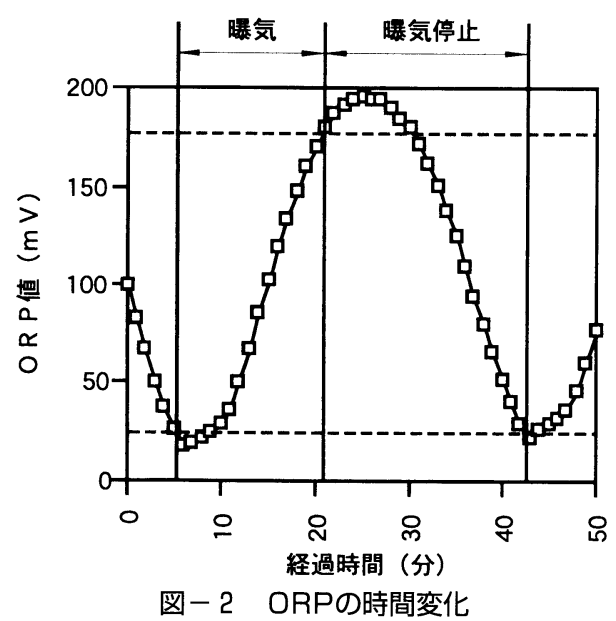

ORP值の変動幅を変化させる運転を行い，水質分析 の結果から最適ORP範囲の推定を行った。なお，用 いた実験装置は 1 基のみで，表 4 の運転条件にした がって実験（各run）を連続的に実施した。なお， この実験中は開始時を除いて膜洗浄は行っていな い. さらに, 反応槽内の状態を調べるために, 細胞 外ポリマー量, 溶解性物質としての糖, タンパク量 の分析も行った。

\section{3 分析方法}

分析項目およびその方法を以下に示す。

SS，VSSは下水試験方法 ${ }^{11)}$ （日本下水道協会編） によった，pH，DOはガラス電極（堀場製作所，D12，OM-14）を用いて測定した。また，ORPはデ ジタルORPコントローラー（TOA，ODIC-7）によ り測定した。化学的酸素要求量 (CODcr) および

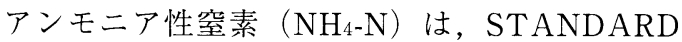
METHODS $^{12)}$ (18th Edition, 1992) によった。全 有機炭素量（TOC）および溶解性有機炭素量 （DOC）は全有機炭素計（島津製作所，TOC-5000） 
表 4 ORP制御運転条件

\begin{tabular}{cccccc}
\hline $\begin{array}{c}\text { run } \\
\text { No. }\end{array}$ & $\begin{array}{c}\text { 期間 } \\
(\text { days })\end{array}$ & $\begin{array}{c}\text { 基質TOC濃度 } \\
(\mathrm{mg} / \ell)\end{array}$ & $\begin{array}{c}\text { TOC負荷 } \\
\left(\mathrm{kg}-\mathrm{TOC} / \mathrm{m}^{3} / \mathrm{day}\right)\end{array}$ & $\begin{array}{c}\text { ORP設定值 } \\
(\mathrm{mV})\end{array}$ & $\begin{array}{c}\text { 最大DO濃度 } \\
(\mathrm{mg} / \ell)\end{array}$ \\
\hline 1 & 7 & 1000 & 0.475 & $0 \pm 10$ & 1.14 \\
2 & 8 & 1000 & 0.475 & $-50 \pm 10$ & 1.28 \\
3 & 7 & 1000 & 0.475 & $50 \pm 10$ & 1.54 \\
4 & 7 & 1000 & 0.475 & $100 \pm 10$ & 0.81 \\
5 & 7 & 1000 & 0.475 & $150 \pm 10$ & 1.37 \\
\hline 6 & 8 & 1000 & 0.475 & $100 \pm 50$ & 1.41 \\
7 & 7 & 1000 & 0.475 & $100 \pm 100$ & 0.05 \\
8 & 8 & 1000 & 0.475 & $50 \pm 50$ & 0.37 \\
9 & 8 & 1000 & 0.475 & $50 \pm 100$ & 0.47 \\
10 & 7 & 1000 & 0.475 & $50 \pm 75$ & 0.62 \\
11 & 7 & 1000 & 0.475 & $100 \pm 75$ & 0.88 \\
\hline $\mathrm{pH}=7.0$ & 処理水流量 $=15 \ell /$ day & 温度 $=28 \sim 33^{\circ} \mathrm{C} \quad$ 滞留時間 $=2.67$ day
\end{tabular}

により測定した。硫酸, 亜硝酸および硝酸イオン $\left(\mathrm{SO}_{4}{ }^{2-}, \mathrm{NO}_{2}{ }^{-}\right.$および $\left.\mathrm{NO}_{3}{ }^{-}\right)$は高速液体クロマトグラ フ法（東ソー, UV-8000）により測定した. 全窒素 （T-N）は，ガスクロマトグラフ法（住友化学工業, GCT-16N+島津製作所，GC-8APT）によって測定 した。また，細胞外ポリマーは，冷温抽出法 ${ }^{9), 13), 14)}$ により抽出し，その糖およびタンパクを測定したも のの和をポリマー量とした．糖分析はAnthrone法 により，タンパク分析はLowry-Folin法により行っ た。

\section{3．実験結果および考察}

3.1 時間制御運転による最適曝気運転条件の推定 MLSS，MLVSSの経日変化を図ー 3 に示す．流 入発酵廃水濃度の増加にともない, MLSSは 16,000 $\mathrm{mg} / \ell$ を超える付近まで増加した. 実験開始130日頃 に，膜洗浄に用いた洗浄剤（次亜塩素酸ナトリウ

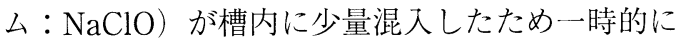
MLSSが低下し，また180日頃に発泡現象による污 泥の流出のため一時的にMLSS が低下した。しかし ながら, 反応槽内に抢ける溶存酸素濃度を抑え，污 泥の自己分解を抑制した結果，MLSSは比較的早く 回復した。以下に処理成績および本実験装置におけ

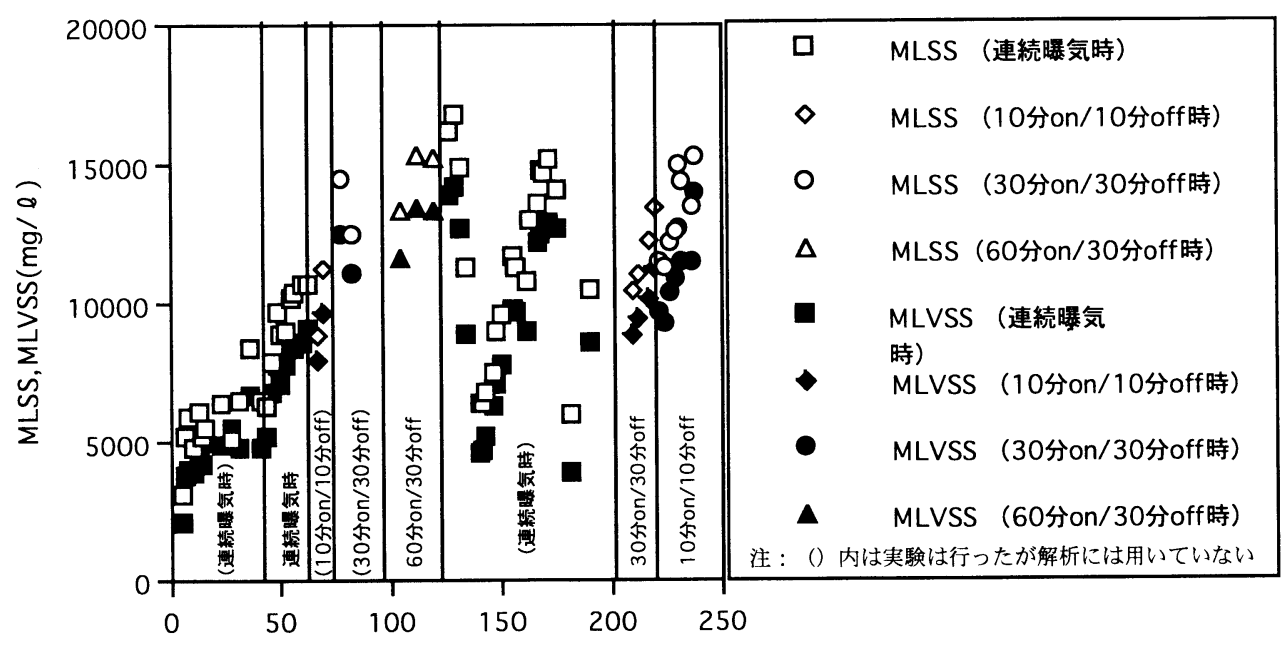

経過日数（日）

図ー3 時間制御運転時のMLSSの経日変化 


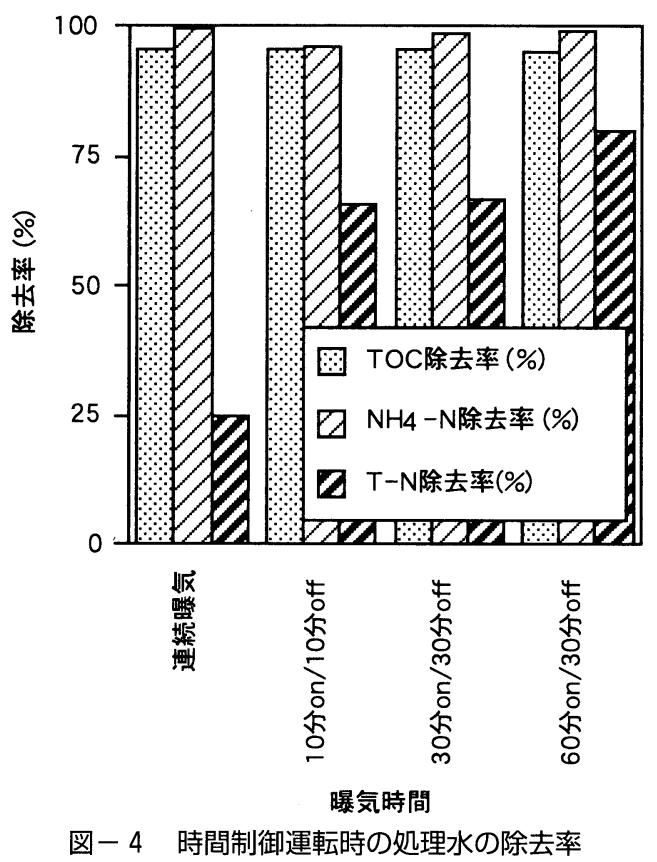

る最適曝気運転条件に関する考察を述べる。

\subsection{1 有機物, アンモニア性窒素および全窒素の 除去特性}

各曝気条件に扔けるTOC， $\mathrm{NH}_{4}-\mathrm{N} ， \mathrm{~T}-\mathrm{N} の$ 除去率 を図ー4 に示す，TOC除去率はいずれの条件にお いても90\%以上の值が得られて抢り，TOCは良好 に処理されていたことがわかる。なお，図一３に各 runの期間を示した。この結果から反応槽内には TOCを分解する細菌を多量に集積できていたと推 定される．また，各曝気条件下に扔いてTOC除去 率に変化は認められなかった。連続的な曝気を行わ なくとも廃水が順調に処理されたことから，曝気運 転条件について経済的改善の可能性が示唆された. 次に $\mathrm{NH}_{4}-\mathrm{N}$ の除去率はほぼ100\%であり，良好な結 果が得られた。これより, 硝化反応は順調に進行し ていたと判断でき，反応槽内には硝化菌が十分に集 積できていたと考えられる。しかし，一定時間を無 酸素状態とした曝気条件では, 連続曝気時に比べ, 多少の除去率の低下がみられた。このことから，一 時的に反応槽内が低酸素の状態になったため硝化反 応が抑制されていたと考えられる.T-Nについては, 連続曝気時に比べ，時間制御時には明らかに除去率 が増加した。これは，時間制御曝気運転により定期 的に反応槽内が無酸素状態となり，脱窒反応が促進 されたからであると考えられる．処理水のNOx-N

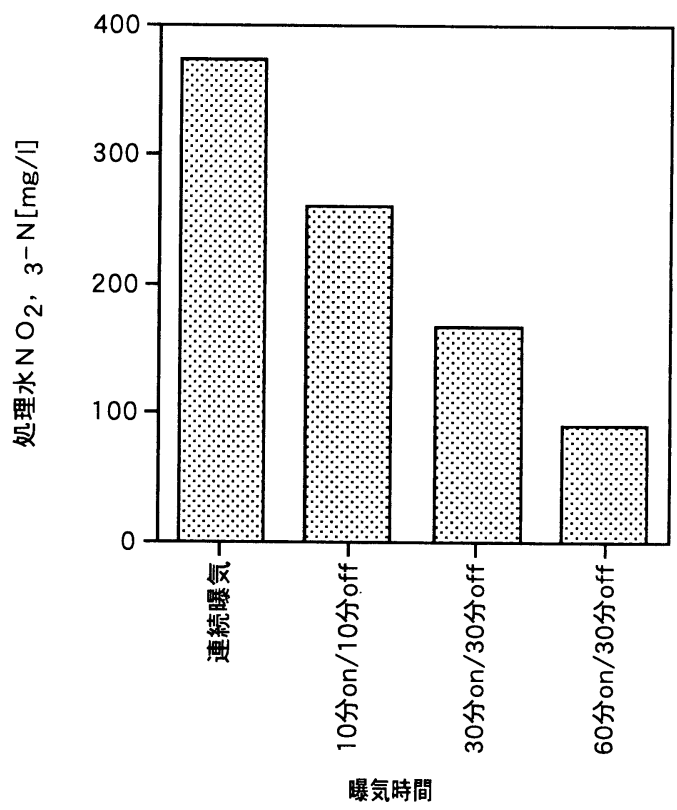

図ー5 時間制御運転時の処理水のNOx-N濃度

濃度（図一5）からも，このことが裏付けられる. 各曝気条件における処理成績を比較すると（図一 $4)$, 間欠曝気運転ではT-N除去率に関しては60分 on・30分offの曝気条件が一番結果が良かったもの の，有機物，およびNH4-Nの除去率にはほとんど差 がなく，曝気運転に要するコストおよび装置に対す る負荷を考慮すると30分on・30分offの曝気条件が 最も有利であると考えられる。

\section{1 .2 時間制御運転における最適曝気運転条件の 推定}

各処理成績結果および考察から，時間制御運転を 行うことによる欠点，すなわち有機物除去率の低下 は認められなかった。また各曝気条件下における有 機物拉よび窒素の処理結果に大きな変化もみられな かった，以上から，本装置での最適曝気運転条件は 曝気に要するコスト面など経済性も考慮して，30分 on・30分offであると推定された.

\subsection{ORP制御運転による最適運転条件の推定}

MLSS，MLVSSの経日変化を図ー6に示す。図 において, 経過日数約70日以後は, ほほ $10,000 \mathrm{mg} /$ $\ell$ で安定した。これは投入基質濃度を $\mathrm{TOC}=1,000$ $\mathrm{mg} / \ell$ と一定濃度に設定したためと考えられる。 MLSSに多少変動はあったものの，10,000〜11,000 $\mathrm{mg} / \ell$ 程度であり, TOCも順調に処理されていたこ とから, 処理は安定していると判断し, 最適ORP值 


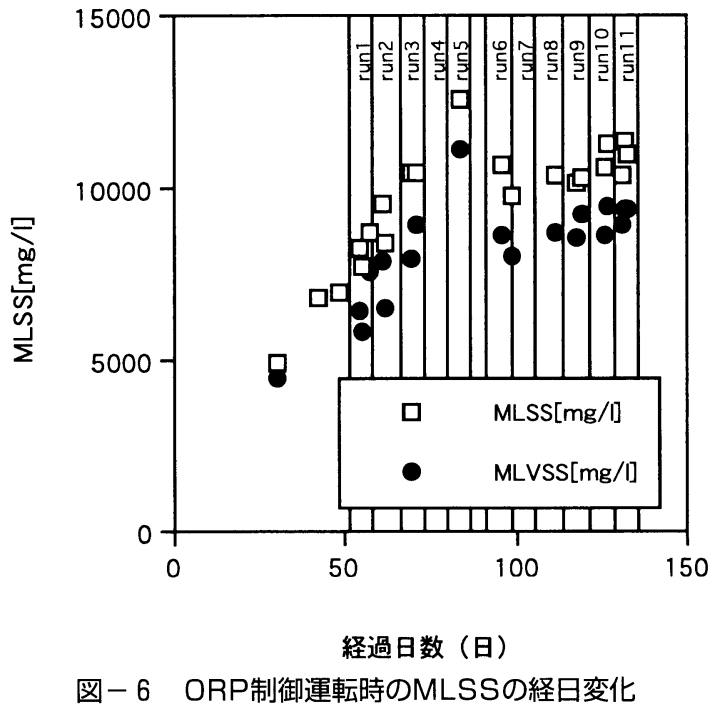

推定実験を行った.

\subsection{1 最適ORP值の推定}

各設定ORP值における運転結果を表 5 に, TOC, $\mathrm{NH}_{4}-\mathrm{N}$ ，T-Nの除去率を図一 7 に示す。TOC除去率 は実験期間を通じて $90 \%$ 以上の值が得られており， TOCは良好に処理されていたことがわかる。この ため, 反応槽内にはTOCを消費する細菌が多く集 積できていたと考えられる。また，ORPが低い值に おいても除去率は高く， $-50 \mathrm{mV}$ 程度の微嫌気的な 状態でもTOC除去は良好に行われていた． $\mathrm{NH}_{4}-\mathrm{N}$ 除去率は設定ORP值が $100 \pm 10 ， 150 \pm 10 \mathrm{mV}$ でほぼ $100 \%$ が得られた. しかしそれ以外の設定值， $-50 \pm$

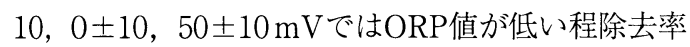
が低かった。これは反応槽内が無酸素あるいは微嫌

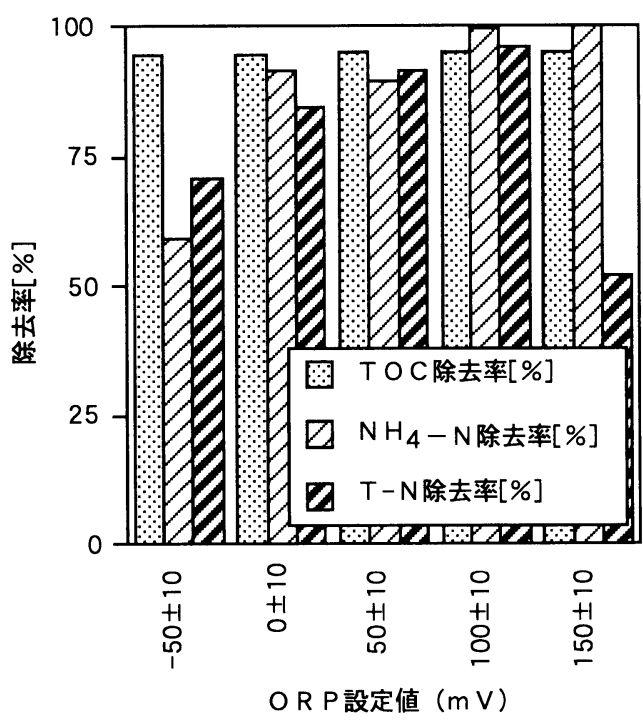

図- 7 最適ORP值推定実験時の処理水の除去率

気的な状態になったため硝化反応が抑制されたこと によると考えられる。T-N除去率については，一 $50 \pm 10 ， 0 \pm 10 ， 50 \pm 10 ， 100 \pm 10 \mathrm{mV}$ と設定ORP 值が高くなるにつれて除去率が上昇したが，設定 ORP值が $150 \pm 10 \mathrm{mV}$ の場合に極端に低下した。こ れは，設定ORP值が高すぎたために槽内が完全酸化 状態となり，脱窒反応が抑制されたためと考えられ る。次に，各条件に扔ける処理水中のNOx-N濃度 を図ー8に示す。この図からも150土10 mVにおい て脱窒反応が抑制されていたことがわかる.

各設定ORP值で処理成績を比較すると，100土 $10 \mathrm{mV}$ の場合にTOC除去および硝化, 脱空が最も良 好に行われており, 最適ORP值は $100 \mathrm{mV}$ 付近であ

表 5 最適ORP值推定実験における運転結果

\begin{tabular}{|c|c|c|c|c|c|c|}
\hline $\begin{array}{l}\text { run } \\
\text { No. }\end{array}$ & & $\begin{array}{c}\text { TOC } \\
\left(m g \cdot \ell^{-1}\right)\end{array}$ & $\begin{array}{c}\mathrm{T}-\mathrm{N} \\
\left(\mathrm{mg} \cdot \ell^{-1}\right)\end{array}$ & $\begin{array}{c}\mathrm{NH}_{4}-\mathrm{N} \\
\left(\mathrm{mg} \cdot \ell^{-1}\right)\end{array}$ & $\begin{array}{c}\mathrm{NO}_{2}-\mathrm{N} \\
\left(\mathrm{mg} \cdot \ell^{-1}\right)\end{array}$ & $\begin{array}{c}\mathrm{NO}_{3}-\mathrm{N} \\
\left(\mathrm{mg} \cdot \ell^{-1}\right)\end{array}$ \\
\hline \multirow{3}{*}{1} & influent & 1040 & 346 & 148 & 0 & 0 \\
\hline & effluent & 59.0 & 99.8 & 60.7 & 8.05 & 0 \\
\hline & removal (\%) & 94.3 & 71.2 & 59.0 & & \\
\hline \multirow{2}{*}{2} & effluent & 56.1 & 54.4 & 13.8 & 3.89 & 28.3 \\
\hline & removal (\%) & 94.6 & 84.3 & 90.7 & & \\
\hline \multirow{2}{*}{3} & effluent & 53.7 & 29.7 & 15.5 & 0 & 7.5 \\
\hline & removal $(\%)$ & 94.8 & 91.4 & 89.5 & & \\
\hline \multirow{2}{*}{4} & effluent & 53.2 & 13.5 & 0.6 & 0 & 5.02 \\
\hline & removal $(\%)$ & 94.9 & 96.1 & 99.6 & & \\
\hline \multirow{2}{*}{5} & effluent & 52.3 & 166 & 0.05 & 0 & 134 \\
\hline & removal (\%) & 95.0 & 52.1 & 99.9 & & \\
\hline
\end{tabular}




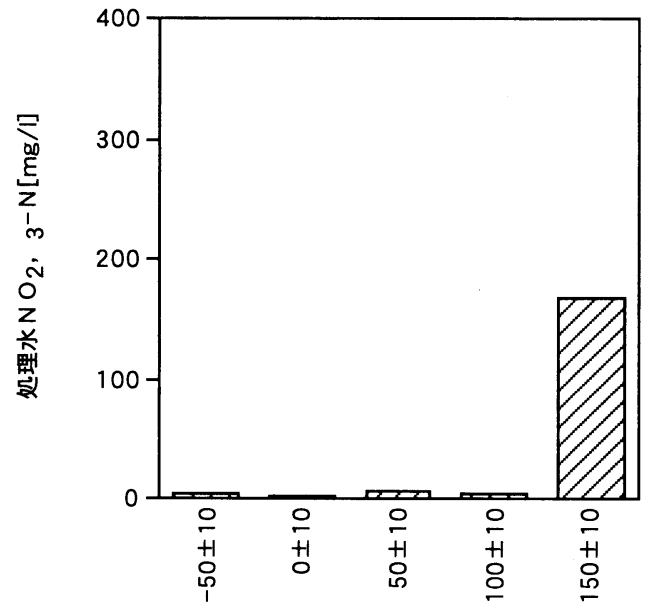

O R P 設定值 $(\mathrm{m} V)$

図-8 最適ORP值推定実験時の処理水のNOx-N濃度

ると推定できる.

\subsection{2 最適ORP範囲の推定}

次に，最適ORP值付近においてORP值にどれほ どの変動を与えれば処理が安定して，あるいは良好 に行えるのかを把握するために以下の実験を行っ た，各ORP設定範囲における運転結果を表 6 に， TOC， $\mathrm{NH}_{4}-\mathrm{N} ， \mathrm{~T}-\mathrm{N}$ の除去率を図ー9に示す. TOC除去率は実験期間を通じて $90 \%$ 以上の值が得 られており，TOCは良好に処理されていたことが

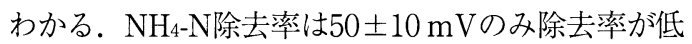
かったことから，ORP值が最大值として $100 \mathrm{mV}$ 付 近に達していれば，硝化反応は順調に行われると考

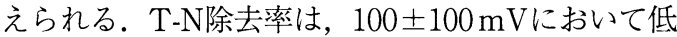
かった。これは前述の通り，設定ORP值が高すぎた ために槽内が完全酸化状態となり，脱窒反応が抑制 されたためと考えられる. 処理水中のNOx-N濃度を 図ー10に示す。NOx-N濃度は100土100 mVにおい て蓄積が認められた。この原因は前述のように槽内 が完全酸化状態であったためと考えられる。図一9

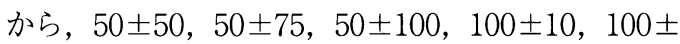
50,100土75の各条件においては処理成績に大きな 差はなく，除去率も良好であったことがわかる．以 上の実験結果および考察から，運転条件として， $100 \mathrm{mV}$ 付近でORP值を $\pm 10 \sim \pm 75$ 程度変動させて も処理成績に差はないと考えられる。一方, $50 \mathrm{mV}$ 付近でORP值の変動を大きくすると処理成績が改善 された．このことから，最適ORP範囲は，50１00 $\mathrm{mV}$ の間に中心を置き，ある程度の変動（ \pm 50 五 $75 \mathrm{mV}$ ) を与えた值であると推定される。 また，時 間制御曝気運転に比べ全搬的に処理成績が向上して いたことから，有機物および窒素の同時除去に対す るORP制御曝気運転の優位性が示されたと考えられ る.

\section{3 曝気に要するコストを考慮した最適運転条件 の推定}

各曝気条件下におけるエアレーションポンプの消 費電力（表 7)，エアレーションポンプの消費電力 と処理水除去率の関係（図-11）を示す．処理水除 去率を比較すると前述の通り時間制御曝気運転時に 比較してORP制御曝気運転時の方が良好であった. また，エアレーションポンプの消費電力は

表 6 最適ORP範囲推定実験における運転結果

\begin{tabular}{clcccc}
\hline $\begin{array}{c}\text { run } \\
\text { No. }\end{array}$ & & $\begin{array}{c}\text { TOC } \\
\left(\mathrm{mg} \cdot \ell^{-1}\right)\end{array}$ & $\begin{array}{c}\mathrm{T}-\mathrm{N} \\
\left(\mathrm{mg} \cdot \ell^{-1}\right)\end{array}$ & $\begin{array}{c}\mathrm{NH}_{4}-\mathrm{N} \\
\left(\mathrm{mg} \cdot \ell^{-1}\right)\end{array}$ & $\begin{array}{c}\mathrm{NO}_{2,3} \mathrm{~N} \\
\left(\mathrm{mg} \cdot \ell^{-1}\right)\end{array}$ \\
\hline & influent & 944 & 334 & 212 & 0 \\
6 & effluent & 44.8 & 16.4 & 0.18 & 3.32 \\
$50 \pm 50$ & removal $(\%)$ & 95.3 & 95.1 & 99.9 & \\
7 & effluent & 54.4 & 14.4 & 0.28 & 4.18 \\
$50 \pm 75$ & removal (\%) 94.2 & 95.7 & 99.9 & \\
8 & effluent & 53.6 & 15.1 & 0.20 & 4.35 \\
$50 \pm 100$ & removal (\%) 94.3 & 95.5 & 99.9 & \\
9 & effluent & 48.0 & 19.3 & 0.31 & 6.52 \\
$100 \pm 50$ & removal (\%) 94.9 & 94.2 & 99.9 & \\
10 & effluent & 52.2 & 13.7 & 0.17 & 2.77 \\
$100 \pm 75$ & removal (\%) 94.5 & 95.9 & 99.9 & \\
11 & effluent & 52.7 & 103.5 & 0.16 & 67.5 \\
$100 \pm 100$ & removal (\%) 94.4 & 84.4 & 99.9 & \\
\hline
\end{tabular}


$\mathrm{ORP}=50 \pm 75,50 \pm 100,50 \pm 50$ $\mathrm{mV}$ の場合にそれぞれ1.12, 1.22 , $1.25 \mathrm{kWh} /$ day, 30分on/30分off の時に $1.26 \mathrm{kWh} /$ dayと大きな差 はなかったが，処理成績を考慮す るとORP制御曝気運転の力に優 位性があることがわかる，以上の ことから, 最適ORP值は50～100 $\mathrm{mV}$ の間に中心に置き, ある程度 の変動 $( \pm 50 \sim \pm 75 \mathrm{mV})$ を与え た值であると推定された.

一方, 曝気に要するコストを比 較する場合に, エアレーションポ ンプのon-offの回数が多いほど消 費電力が大きくなることが予測さ れる。したがって曝気を開始した 直後の電力消費に関する実験的検 討を行った，曝気を開始した直後 のエアレーションポンプの電力消 費曲線を図ー12に示す。この図の ように曝気を開始した直後に消費

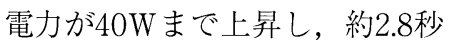
から後は15W付近で安定した。 この曲線から曝気開始 1 回に対す る電力の増加量を計算し, 1 時間 あたりのエアレーションポンプの 定常運転の消費電力と比較する と，無視できる程度であった。す なわち，本実験における各曝気条 件での 1 時間あたりの曝気開始の 回数の違いは 1,2 回程度であり

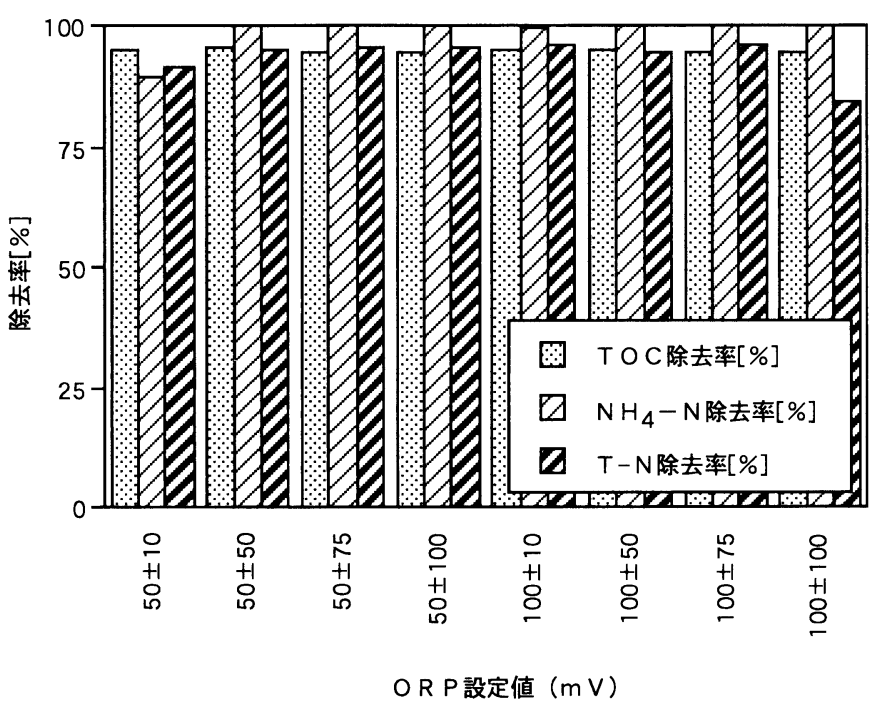

図-9 最適ORP範囲推定実験時の処理水の除去率

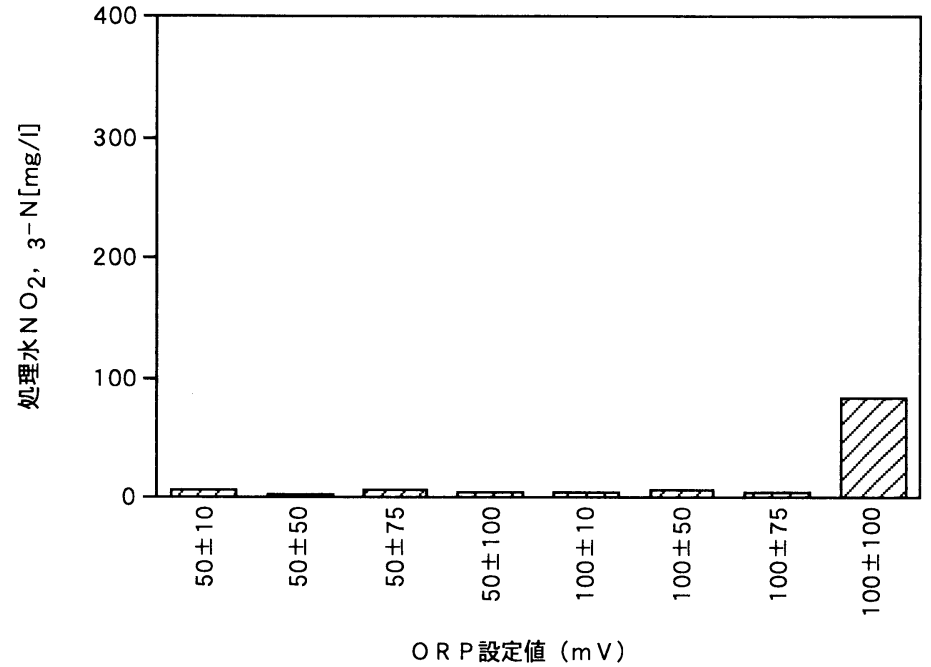

図-10 最適ORP範囲推定実験時の処理水のNOx-N濃度

表 7 各曝気条件下の消費電力

\begin{tabular}{|c|c|c|c|c|c|c|}
\hline $\begin{array}{c}\text { ORP設定値 } \\
(\mathrm{mV})\end{array}$ & $50 \pm 50$ & $50 \pm 75$ & $50 \pm 100$ & $100 \pm 50$ & $100 \pm 75$ & $100 \pm 100$ \\
\hline $\begin{array}{c}1 \text { サイクルの時間 } \\
(\mathrm{min})\end{array}$ & 26.9 & 35.8 & 47.4 & 30.2 & 38.4 & 83.9 \\
\hline $\begin{array}{c}\text { 曝気時間 } \\
(\mathrm{min})\end{array}$ & 13.3 & 15.9 & 23.0 & 17.5 & 20.5 & 58.5 \\
\hline $\begin{array}{c}\text { 曝気停止時間 } \\
(\mathrm{min})\end{array}$ & 13.6 & 19.9 & 24.4 & 12.7 & 17.9 & 25.4 \\
\hline $\begin{array}{c}\text { 消費電力 } \\
(\mathrm{kWh} / \text { day })\end{array}$ & 1.25 & 1.12 & 1.22 & 1.46 & 1.35 & 1.76 \\
\hline $\begin{array}{l}\text { 曝気開始の回数 } \\
(\text { 回/h) }\end{array}$ & $2 \sim 3$ & $1 \sim 2$ & $1 \sim 2$ & $1 \sim 2$ & $1 \sim 2$ & $0 \sim 1$ \\
\hline
\end{tabular}

30分on $/ 30$ 分off時 消費電力 $=1.26(\mathrm{kWh} / \mathrm{day})$ 曝気開始の回数 $=1($ 回 $/ \mathrm{h})$ 


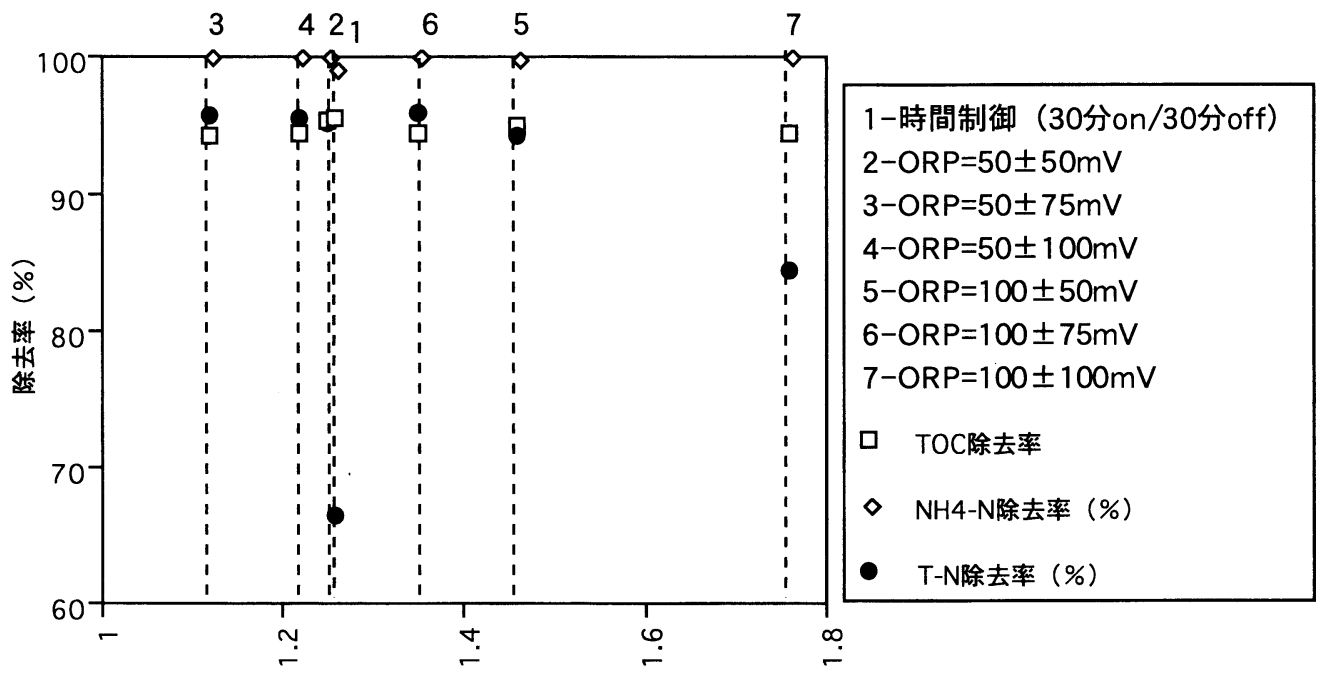

消費電力 (kWh/day)

図一11 消費電力に対する処理水除去率

(表 7)，エアレーションポンプの消費電力に対する 影響は無視できると考えられる。

\section{4 細胞外ポリマーおよび溶解性物質としての} 糖・タンパクに関する検討

反応槽内の発泡は，平常時には菌に付着する形で 存在するポリマーが污泥の高濃度化，さらにpHの 上昇等のアクシデントにより剥離し，高分子溶解性 物質として反応槽に溶出するために生じると考えら れる ${ }^{9)}$. ORP制御時，発泡時（図一 3 の180日頃）, 下水処理場の活性污泥の細胞外ポリマー量（図一 13），溶解性物質としての糖・タンパク量（図一14） をそれぞれ示す。図からORP制御時の細胞外ポリマ 一量は発泡時の約1.5倍存在していたことがわかる. 反対に溶解性物質としての糖・タンパク量は発泡時

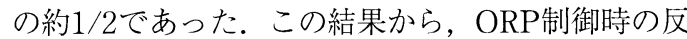
応槽内は安定した状態であったと考えられる。次に 最適ORP值および最適範囲推定実験時の細胞外ポリ マー量を図ー15に示す。この図から細胞外ポリマー 量についてORP值，ORP範囲による違いは認めら れなかった．溶解性物質としての糖・タンパク量は ORP值が上昇すると減少する傾向がみられた（図一 14)。したがって，ORP值が高い方が反応槽内に 糖・タンパクの蓄積が少ないことが推測される.

\section{4. 結言}

本研究で得られた結果を以下にまとめる.

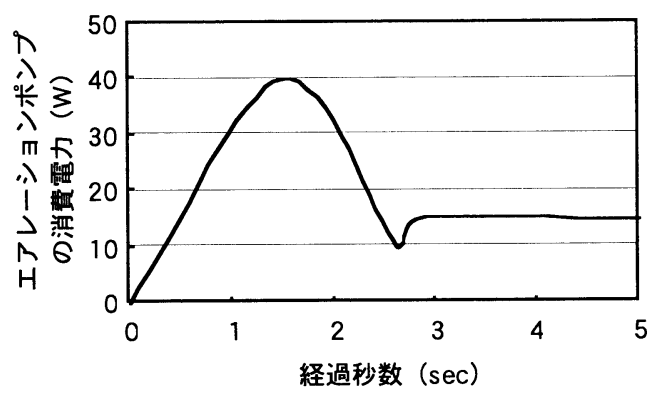

図-12 懪気開始直後の電力消費曲線

（1）処理成績結果から，時間制御あるいはORP制御 曝気運転を行うことによる有機物除去率の低下等の 欠点は認められなかった。

（2）時間制御曝気運転における最適時間制御運転条 件は曝気に要するコスト面など経済性を考慮し，30 分on/30分offであると推定された。

（3）処理成績等から，有機物・窒素の同時除去にお ける時間制御曝気運転に対するORP制御曝気運転の 優位性が示され，最適ORP值は50～100 mVの間に 中心に置き，ある程度の変動（土50～ $\pm 75 \mathrm{mV} ）$ を 与えた值であると推定された。

（4）溶解性物質としての糖・タンパク量はORP值が 上昇すると減少する傾向がみられた。すなわち， ORP值が高い方が反応槽内に糖・タンパクの蓄積が 少ないことが推測された。 


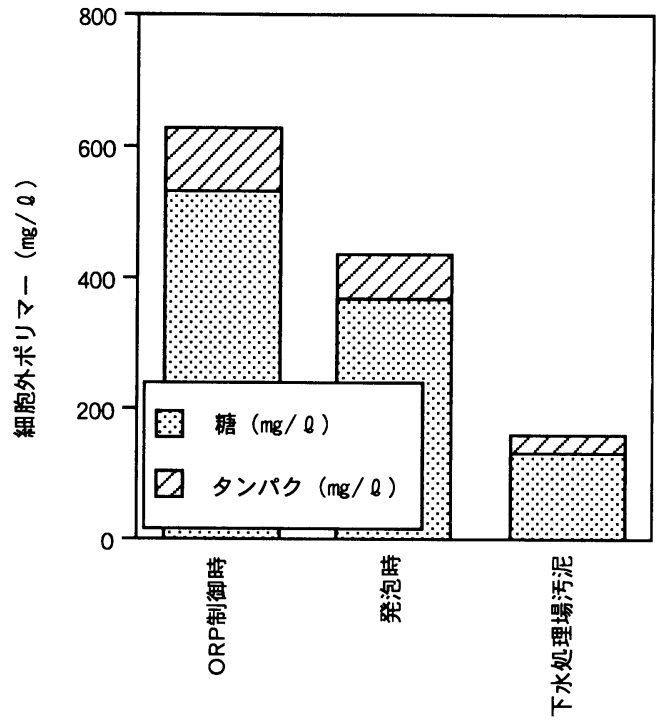

図一13 ORP制御時, 発泡時, 下水処理場污泥の 細胞外ポリマー

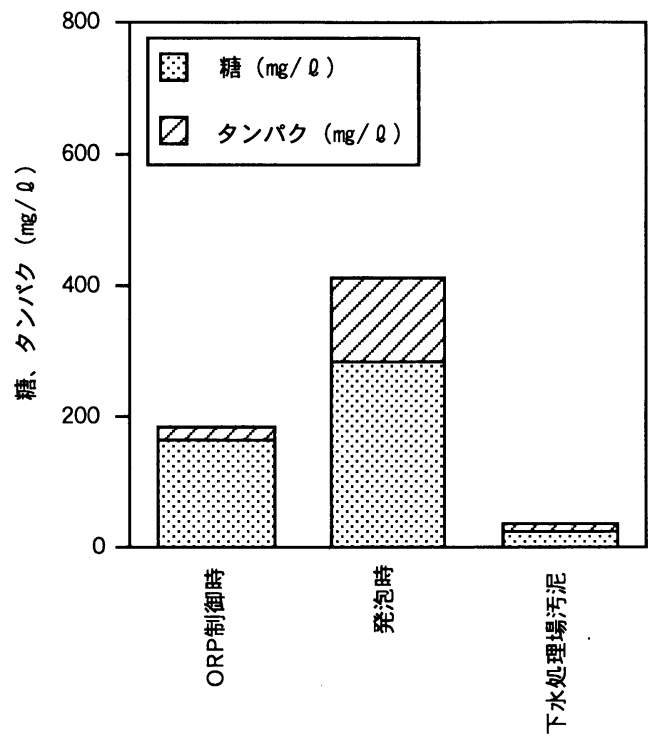

図一14 ORP制御時, 発泡時, 下水処理場污泥の 溶解性物質としての糖・タンパク質

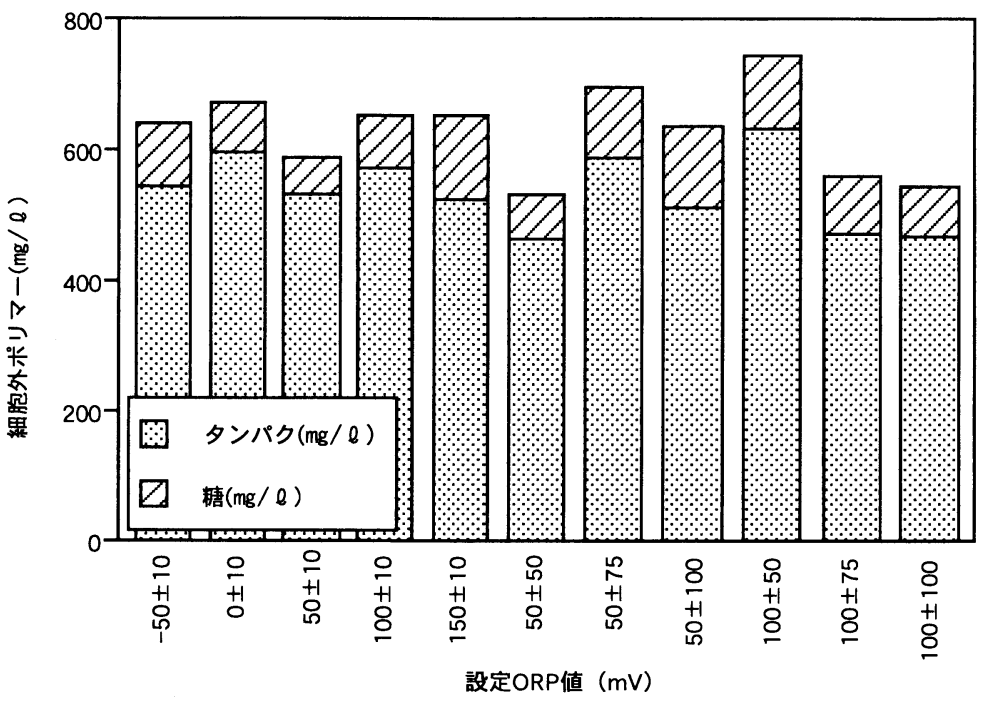

図ー15 最適ORP值ならびに最適ORP範囲推定実験時の細胞外ポリマー量

謝辞：本研究は，一部財鉄鋼業環境保全技術開発基金の環境 分野助成を受けて行った．記して謝意を表します。また，回 転平膜装置を提供いただきました日立プラント建設侏に深甚 なる謝意を表します。

\section{参考文 献}

1 ) 大庭真治, 堺 好雄：単槽式嫌気好気活性污泥法の設計 手法の提言，下水道協会誌論文集，31（370） pp.34-48, 1994.
2 ) 宗宮 功, 津野 洋, 山下洋正 : 間欠曝気式膜分離活性 污泥法に打ける窒素除去特性に関する研究，下水道協会 誌論文集, 33 (407) pp.104-118, 1996.

3 ) 藤井正博, 岡村宣夫, 庄司 敦: ORP制御を組み込んた 回分式活性污泥法による高度処理, 用水と廃水，29(4) pp.346-353, 1987.

4 ）藤井正博, 三木 理, 嘉森裕史：下水のCOD, りん及び 窒素の高効率処理の研究-ORP制御活性污泥処理パイロ ットプラントによる性能評価一, 下水道協会誌論文集, 30 (364) pp.96-107, 1993.

5 ）大熊那夫紀，鈴木恒雄，松井敏一，青井 透：回転平膜 モジュールを用いた粉末活性炭添加型凝集処理の検討, 環境工学研究論文集, vol.34, pp.93-99, 1997. 
6 ）木村克輝, 渡辺義公, 大熊那夫紀 : 回転平膜に付着した 生物膜による低濃度アンモニア性窒素の硝化特性, 土木 学会論文集, No.552/VII-1，pp.43-52，1996.

7 ) N. Ohkuma, T. Shinoda, T. Aoi, Y. Okaniwa and Y. Magara : Performance of rotary disk modules in a collected human excreta treatment plant, Wat. Sci. Tech., 30 (4), pp.141-149, 1994.

8 ) 増田 等, 大熊那夫紀 : 回転平膜モジュールを用いた生 物学的窒素除去法, ケミカルエンジニヤリング, 36 (11) pp.966-973, 1991.

9 ) 今井 剛, 呂 樹光, 浮田正夫, 関根雅彦, 中西 弘, 深川勝之 : 回転平膜を用いた膜分離高濃度活性污泥法に おける污泥の活性度の変化に関する研究, 環境工学研究 論文集, vol.35, pp.319-328，1998.

10) S. G. Lu, Tsuyoshi Imai, Masao Ukita, Masahiko
Sekine, Hiroshi Nakanishi and Masayuki Fukagawa : Characterization of highly concentrated activated sludge in fermentation wastewaster treatment coupled with UF membrane, J. Environ. Syst. and Eng., JSCE, No.622/VII-11, pp.95-105, 1999.

11）社日本下水道協会：下水試験方法-1984年版一

12) APHA, AWWA and WPCF : Standard Methods for the Examination of Water, 18th edition, American Public Health Association, Washington D.C., 1992.

13) Sutherland I. W. and Wilkinson : Chemical Extraction Methods of Microbial Cells, " Methods in Microbiology” Chap. IV, Vol. 5B, Academic Press, 1971.

14）久場隆広，古米弘明，楠田哲也：細胞外ポリマーの簡易 抽出法に関する検討, 土木学会第29回環境フォーラム講 演集, B-21, 1992.

\title{
Study on Simultaneous Removal of Organic Matters and Nitrogen with Aeration Control in Highly Concentrated Activated Sludge Process Using Disk Type UF Membrane
}

\author{
Tsuyoshi IMAI, Shuguang LU, Masao UKITA, Masahiko SEKINE, \\ Takaya HIGUCHI and Masayuki FUKAGAWA
}

\begin{abstract}
A study has been made on optimal operating condition capable of carrying out simultaneous removal of organic matters and nitrogen in a highly concentrated activated sludge process using rotary disk type UF membrane as liquid-solid separator.

From the experimental results, the optimal condition for operating time control aeration is deduced to be 30-min., aeration on and 30-min, aeration off, from the aspect of economic advantages such as costs involved in aeration .

The optimal operation in this study was found at ORP centering about 50 to $100 \mathrm{mV}$, with a certain level of fluctuation ( \pm 50 to $\pm 75 \mathrm{mV}$ ).

Key Words : activated sludge process, rotary disk type UF membrane, fermentation wastewater, intermittent aeration, removal of organic matters and nitrogen.
\end{abstract}

